Ankara Üniversitesi

SBF Dergisi,

Cilt 70, No. 2, 2015, s. 317 - 344

\title{
GÜĢ MESAFESI YÜKSEKSE EŞitSizLiK Mi ISTENIR?
}

\section{Nurcan Kemikkıran}

Başkent Üniversitesi

Doktora Öğrencisi

\section{Öz}

Çalışmada, güç kavramı incelenmiş, gücün kaynakları araştırılmış ve kültürel anlamda güç mesafesi konusu incelenmiştir. Güç mesafesi yüksek toplumlarda, gücün örgüt düzeyine, grup düzeyine ve birey düzeyine yansımaları araştırılmıştır. Bu tür toplumlarda, güç sahibi olanların kalıp yargılarla karar verme eğiliminin, grup kalıp yargılarının ve grup içi önyargıların daha fazla olmasının beklenebileceği, grup kalıp yargılarının ve grup içi önyargıların da etkisiyle grup içi kayırmacılık eğiliminin artabileceği önerilmiştir. Ayrıca, eşitliğe muhalefet ile gruba dayalı baskınlık eğiliminin, grup içi kayırmacılık ve gruplar arası ayrımcılığa, grup içi kayırmacılığın da gruplar arası ayrımcılığa neden olabileceği önerilmiştir. ayrımcilık

Anahtar Sözcükler: Güç, güç mesafesi, kalıp yargı, grup içi kayırmacılık, gruplar arası

\section{Is Inequality Desired When Power Distance is High?}

\section{Abstract}

In this study, the concept of power is discussed, sources of power are examined and power distance from a cultural perspective is investigated. The effects of power on organizations, groups and indivuals in societies with high levels of power distance are examined. It is proposed that, in societies with high levels of power distance, power holders have a high tendency to give decisions based on stereotyping, group stereotyping, in-group bias, and the tendency of in-group favoritism are expected to be higher. In addition, within groups of high status, in-group favoritism can be expected to be even higher and this can cause intergroup discrimination.

Keywords: Power, power distance, stereotyping, in-group favoritism, intergroup discrimination

\footnotetext{
* Makale geliş tarihi: 23.07.2014
}

Makale kabul tarihi: 27.01.2015 


\section{Güç Mesafesi Yüksekse Eşitsizlik mi İstenir?}

\section{Giriş}

Sosyal bilimlerin en önemli kavramlarından olan güç, pek çok olguya yön vermekte ve sosyal ilişkileri şekillendirmektedir. Güç, farklı yollarla elde edilse de güç ile birlikte kaynaklara sahip olma ve onları yönetme yetisi elde edilmektedir. Güçlü olan bireyler, gruplar veya örgütler diğer birey, grup veya örgütlerin çıktılarını denetleyebilmekte ve diğerlerine karşı daha az bağımlı olmaktadır.

Kültürel anlamda ise güç, kültürün güç mesafesini şekillendirmekte, toplumsal kültür çalışmalarının bir boyutu da güç mesafesi olarak ifade edilmekte ve toplumlar güç mesafesi yüksek ve düşük olarak ikiye ayrılmaktadır (Hofstede, 1983a). Güç mesafesinin yüksek olması, güçlünün güçsüzden farklı olması, kararların güçlüler tarafından verilmesi, güçlünün ayrıcalıklara sahip olması, toplumda var olan eşitsizliğin taraflar tarafindan kabul edilmesi olarak tarif edilebilir. Bir toplumda yaşayan, varlığını sürdüren bireylerin, grupların ve örgütlerin, toplumun güç mesafesini yansıttığı varsayılmaktadır. Başka bir deyişle, toplumun güç mesafesi yüksekse, bireyler, gruplar ve örgütler de, güç mesafesi yüksek olan toplumun özellikleri doğrultusunda hareket etmektedir.

Çalışmada, güç mesafesi yüksek toplumlarda, gücün örgüt düzeyine, grup düzeyine ve birey düzeyine ne tür yansımaları olabilir, güç, grup içi-grup dışı kayırmacılığa yol açar mı? Sorusuna yanıt aranmıştır. İlk aşamada, güç kavramı incelenmiş, gücün kaynakları araştırılmış ve kültürel olarak güç mesafesi konusu incelenmiştir. Ülkemizin de içinde yer aldığ 1 güç mesafesi yüksek olan toplumlarda, kalıp yargılar, ön yargılar ile grup-içi, grup-dışı kayırmacılık konularına değinilmiş ve son olarak da gruba dayalı baskınlık ve eşitliğe muhalefet konuları araştırılmıştır.

Ulusal yazında; Yılmaz (2014), Balaban (2013), Yıldırım ve Akgün (2013), Bayram (2008) ve Karaçanta (2002) tarafından yapılan çalışmalar yer almaktadır. Sosyal kimliğin gruplar arası çatışmalar üzerindeki etkisi Yılmaz (2014) tarafından, Türklerin Kürtlere yönelik önyargıları ve algılanan tehdidin 
bu önyargıdaki etkisi ise Balaban (2013) tarafından araştırılmıştır. Ayrıca, Yıldırım ve Akgün (2013), Sivil Toplum Kuruluşları gönüllülerinin dünyanın adaleti hakkındaki algıları, gruplar arası hiyerarşiyi destekleme eğilimleri, sosyal sistemin meşruiyetine ilişkin algıları üzerine çalışma yapmıştır. Bayram (2008) ise etik paradigmalar, biyolojik cinsiyet ve cinsiyet şemaları arasındaki ilişkiler ile bu olguların sosyal baskınlık yönelimi üzerindeki etkilerini araştırmıştır. İlave olarak, sosyal baskınlık yönelimi, vatanseverlik, grupla özdeşleşme, adaletsizlik algısı ve gruba bağlılık arasındaki ilişkiler ile etnik gruplar karşılaştırılarak, statü algısı, sosyal baskınlık yönelimi, vatanseverlik, grup içi özdeşleşme, adaletsizlik algısı ve gruba bağlılık yönünden farklılıklar Karaçanta (2002) tarafından çalışılmıştır. Ancak, ulusal yazında grup içi kayırmacılık, grup dışı kayırmacılık ve gruplar arası ayrımcılık olgularını, kültürel anlamda güç mesafesi ile inceleyen başkaca çalışmaya rastlanmamış olmasının mevcut çalışmanın önemini artıracağı ve alana katkı sağlayacağı değerlendirilmektedir.

\section{Güç Kavramı}

Güç, sosyal yaşamın ve sosyal yapının kaçınılmaz bir özelliği ve sosyal bilimlerin anahtar kavramıdır (Turner, 2005: 1). Sosyal ilişkileri tanımlayan özelliklerin en önemlilerinden biri güç, daha doğrusu güç farklılığıdır (Rodríguez-Bailón vd., 2000:651; Turner, 2005:1). Votaw (1966: 74)'a göre güç terminolojisinde bir karışıklık bulunmakta, güç, otorite ve etki ile karıştırılmaktadır. Bu karışıklıktan kurtulmak üzere Votaw (1966), geleneksel güç kavramının, baskı ve şiddetin güçlü tarafından zayıfa uygulanması olan "çıplak gü̧̈" kavramı, "yönetenler ve yönetilenler" kavramı, gücün suistimali ve yozlaşması dolayısıyla "kaçınılmaz bela" kavramı, birinin düşüncesi ile diğerinin çıktısını etkilemesi olan "sınırlı arz" kavramı, etik, dini, ahlaki yönleri ile "ahlak" kavramı, gücü yapıcı olarak gören "Hobbes'un geleneksel güç kavramı" olarak kavramlaştırılabileceğini öne sürmektedir. Dolayısıyla, geleneksel güç kavramı, gücü daha çok siyasi güç olarak algılamakta, modern güç kavramı ise sosyal yaşamın tüm aşamalarını kapsamaktadır (Votaw, 1966: 81).

Gücün kaynaklarına bakılacak olursa; güç, saldırıyı başlatmak, ödül vermek, tehdit etmek gibi gücün belirli kullanımlarından değil, gücün yapısal potansiyelinden (De Dreu ve Van Kleef, 2004: 304), hedeflere ulaşmanın kolaylaştırılmasından değil, hedefi kisıtlayan engellerin oluşumunun azaltılmasından (Whitson vd., 2013: 582), güç sahibi olanların denetim algısından değil, güçlü olanların daha esnek düşünebilme potansiyelinden ve hedeflerin benimsenmesinin güç sahibi olanların meşruiyetini en üst seviyeye çıkarmasından (Overbeck ve Park, 2006: 240) ve sosyal kurumların desteği, 
fiziksel beceri, sayısal üstünlük veya algilanan meşruiyetten (Ebenbach ve Keltner, 1998:8) kaynaklanabilmektedir. Salancik ve Pfeffer (1977: 8-9)'a göre gücün kıt ve kritik kaynaklar etrafinda toplanması güç savaşlarını beraberinde getirmekte buna karşın bol olan bir kaynağın tahsisini veya neyin kritik olduğunu belirlemekle de elde edilebilmektedir. $\mathrm{Bu}$ nedenle, güç pek çok toplumda kritik kaynakların etrafinda toplanmakta, çok az toplumda bol kaynakların etrafında toplanmaktadır (Salancik ve Pfeffer, 1977: 8-9). Başka bir deyişle güç, olumlu olarak değerlendirdiğinde kaynağa sahip olma veya ulaşma, olumsuz olarak değerlendirdiğinde ise kaynakların eşit olmayan şekilde tahsis edilebilme kapasitesinden kaynaklanabilmektedir (Magee ve Galinsky, 2008:361). Öte yandan, Overbeck ve Park (2006: 242) gücün kaynaklar yanında ilişkiler, roller bağlamında da belirlendiğini vurgulamaktadır.

Güçle birlikte anılan önemli kavramlardan biri denetim yetisidir. Güç, kendi çıktılarını denetleyebilme, güçsüzlük ise kendi çıtıları üzerinde denetim sahibi olamama olarak tanımlanmaktadır (Rodríguez-Bailón vd., 2000: 652; Goodwin vd., 2000: 228). Güç farklılıkları, çıktı denetimindeki farklılıkları (Rodríguez-Bailón vd., 2000: 651-652; Goodwin vd., 2000: 228) yansıtmaktadır. Güçle birlikte anılan diğer önemli kavramlardan biri ise bağımlılıktır. Sosyal ilişkiler çoğunlukla taraflar arasında karşılıklı bağımlılık ilişkilerine yol açmakta (Emerson, 1962: 32) dolayısıyla güç ilişkilerdeki bağımlılığı yansıtmaktadır (Goodwin vd., 2000: 228; De Dreu ve Van Kleef, 2004: 304; Molm, 1988: 109; Emerson, 1962: 32; Magee, 2009: 2). Kişiler, diğerlerine bağımlı olduğunda, o kişileri yakından inceleyerek onların davranışlarını ve niyetlerini doğru bir şekilde öngörerek, kendi çıktıları üzerinde denetimi sağlamak veya elde tutmak istemektedir (De Dreu ve Van Kleef, 2004: 304; Emerson, 1962: 32). Bu nedenle, diğerini etkileme veya denetim altına alma gücü, değer verilen şeylere göre değişmekte, bunlar ilişkiye bağlı olarak petrol kaynaklarından benlik desteğine kadar geniş bir yelpazede yer almaktadır (Emerson, 1962: 32). Bağımlılık ise sağlanan kaynağın değeri ile artarken, alternatif kaynakların varlığ 1 ile azalmaktadır (Molm, 1988: 109). Güç-bağımlılık kuramına göre yapısal güçte yani bağımlılıklar arasında asimetri olduğunda buna bağlı olarak davranışsal güçte yani ödüllerin değiştokuşunda da asimetri oluşmaktadır (Molm, 1988: 110).

Emerson (1962: 32) bağımlılık ve gücü aşağıdaki gibi tanımlamıştır;

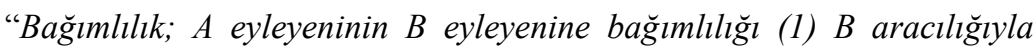
sağlanan hedeflerde A'nın motivasyonu ile doğru orantılı (2) A-B arasındaki ilişki olmadan o hedeflere $A$ tarafindan ulaşllabilme olasılığlyla ters orantılıdır... Güç; A eyleyeninin $B$ eyleyeni üzerindeki gücü, B tarafindan uygulanan direncin, $A$ tarafindan aşllabilme olană̆ıdır." 
Molm (1988: 109)'a göre güç-bağımlılık kuramının temeli iki eyleyen arasındaki etkileşimlerin sonucu olarak gerçekleşmekte, eyleyenin biri diğeri için fiziksel, sosyal, psikolojik çıktı ürettiğinde değiş-tokuş ilişkileri bir ağ içinde gerçekleşmektedir. Eyleyenlerin birbirine bağ 1 mlılığ 1 , güç, tutarlılık ve güç farklılığının belirleyicisi olup, A-B ilişkisinde A'nın gücü, B'nin A'ya bağımlılığ 1 , tutarlılık, iki aktörün birbiri üzerinde güç/bağımlılığının ortalaması, güç farklılığ 1 ise iki aktörün güç/bağımlılığının fark1 olarak tanımlanmaktadır (Molm, 1988: 109).

Bağımlılık ve denetim açısından tarafların ve kaynakların durumu farklılık göstermekte, bu durum hiyerarşik rütbe ile kendini göstermekte, yöneticilerin astlarına olan bağımlılığı, astlarının onlara olan bağımlılığından daha az olmaktadır (Magee, 2009: 2). Bu durum da örgütlerde kendini hiyerarşi ile göstermekte, hiyerarşi tüm örgütlerde çeşitli şekillerde yer almakta, örgütlerin piramit şeklinde yapısından dolayı üst tabakada daha az kişi yer almaktadır (Magee ve Galinsky, 2008: 352). Diğer yandan güç farklılıkları, aynı seviyede olanlar arasında bile görülebilmekte, biri diğerine tavsiye, yönlendirme veya duygusal destek açısından bağımlı olabilmekte ve bu durum da güç farklılıkları yaratabilmektedir (Magee, 2009: 2). Güç yoluyla pek çok ilişkide, iki taraftan birinin daha güçlü olduğu veya hiyerarşide daha üst düzeyde olduğu dikte edilmektedir (Leikas vd., 2013: 155).

Bağımlılık ve denetimden farklı olarak güce ilave tanımlar da getirilmektedir. Güç, başkalarını etkileme yeteneği (Ayman vd., 1995: 157; Krackhardt, 1990: 359; Koslowsky vd., 2001: 455) olayların istenilen şekilde yapılmasını sağlama yeteneği (Salancik ve Pfeffer, 1977:4) olarak da tanımlanmaktadır. Krackhardt (1990: 359) gücün gücü yani meta gücü, diğerlerinin gücünü bilme ve birini etki altına almak için diğerlerinin gücünü de kullanma olarak tanımlamıştır. Ayrıca gücün, sosyal davranış veya sosyal muhakeme üzerinde önemli etkileri vardır (Leikas vd., 2013: 155). Şöyle ki, Goodwin vd. (2000: 227)'ne göre güçlü kişilere toplum tarafından diğerlerini yargılamak üzere onay verilmiştir: Hâkimler suçluyu belirlemek, öğretmenler öğrencilere not vermek ve yöneticiler çalışanları terfi ettirmek amaciyla değerlendirme yaparlar. Güç sahibi olanlar diğerlerinin kaynakları (Overbeck ve Park, 2006: 230; Sachdev ve Bourhis, 1991: 21), firsatları, ödülleri hakkında karar almakta ve diğerlerinin performansını değerlendirmektedir (Overbeck ve Park, 2006: 230).

Güç ile statü, otorite ilişkisine bakılacak olursa; güç, eyleyenin sahip olduğu, kaynak temelli iken, statü başkaları tarafından verilmekte, bu nedenle güç, statüden daha fazla eyleyenin özelliği olmakta, statü ise güçten daha fazla ortak eyleyenler ve gözlemcilerin özelliğini yansıtmaktadır (Magee ve Galinsky, 2008: 363-364). Magee ve Galinsky (2008: 364)'ye göre, güç ve statü, birbiriyle nedensel olarak ilgili olabilmekte ve birbirini karşıllıklı olarak 
pekiştirebilmekte, güç statü verebilirken statü gücü sağlayabilmektedir. Başka bir deyişle, güç sıklıkla statüye yol açarken, gücü olmayan statü veya statü olmadan güce sahip olanlar da görülebilmektedir (Magee ve Galinsky, 2008: 363-364). Güç statüleri değiştiğinde buna paralel olarak davranışlarda değişiklik gözlenebilmektedir (Leikas vd., 2013: 155). Otorite ise Emerson (1962: 38) tarafından, "meşruiyet" süreci ile gücün dönüşümü olarak tanımlanmıştır. Ayrıca, bir kişinin otoritesini meşrulaştırmak, diğerlerinin meşruiyetini azaltmak yoluyla gücün kurumsallaşması sağlanabilmektedir (Salancik ve Pfeffer, 1977: 18-19).

Özetlemek gerekirse, güç, toplumdaki olayları, sosyal düzeni, sosyal ilişkileri şekillendirmekte önemli rol oynamaktadır. Güç, en başta bağımlılık ve denetim olmak üzere pek çok yolla elde edilebilmektedir. Güç olumlu olarak kendini gösterebileceği gibi olumsuz olarak da kendini gösterebilmektedir.

Votaw (1966: 74)'a göre;

"Güç, tüm siyasi, sosyal, ekonomik ve diğer tip güç sistemlerinin hem içinde hem arasında karşıllklı bir iliş̧kidir; miktar ve şsekle göre sürekli değişir ve dinamiktir; toplumun en önemli kaynaklarından biridir ancak, zenginlik ve diğer kaynakların pek çoğu gibi suistimale ve yozlaşmaya açıtıtı"

Güçle ilgili en temel sorun, suistimali ve yozlaşmayı engelleyecek denetimi sağlayarak gücün etkin kullanımını sağlamaktır (Votaw, 1966: 85). Kritik nokta şudur ki, güç, etkililik, verimlilik ve koordinasyon için gereklidir ancak aynı özellikler suistimal için de potansiyel oluşturmaktadır (Overbeck ve Droutman, 2013: 1474). Diğer yandan, sosyal çatışmalar hemen hemen her zaman iki tarafın, kendi çıktılarını bazen de başkalarının çıktılarını denetleme yeteneğine sahip olma veya sürdürme için güç pazarlıkları etrafinda dönmektedir (Ebenbach ve Keltner, 1998:8). Gayrimeşru güç, sosyal karşılaştırma sürecini rakipler hakkında bilgi elde etmek için artırabilmektedir (Johnson ve Lammers, 2012: 333).

\section{Güç Mesafesi}

Sosyo-kültürel yapı, birey ve grup davranışlarını etkileyen en önemli unsurlardan biridir ve bir kültürün üyeleri, olayları ve durumları genellikle benzer şekilde yorumlayacak ortak değerlere sahiptir (Khatri, 2009: 1-2). Kültürün dört boyutu (güç mesafesi, belirsizlikten kaçınma, bireyselcilik/ toplulukçuluk, eril/dişil) bir toplumun karş1 karşıya kaldığ 1 temel sorunlara nasıl yanıt bulduğu ile ilgilidir (Hofstede, 1983a: 46). Kültüre ilişkin dört boyuta, birey bazında değil de toplum bazında değer sorularına verilen 
yanıtların ortalama puanları alınarak "ekolojik analiz" olarak tanımlanan ölçüm sonucunda erişilmektedir (Hofstede, 1985: 348).

Güç mesafesi endeksi, ülke değerlerinin üç ögesi olan; a) amirlerinin kararlarını verirken otokratik ve inandırıcı olduğunu algılayan astların oranı b) astların, çalışanların genel olarak amirleri ile aynı fikirde olmamaktan korktuklarını algılaması c) amirlerinin danışarak değil de otokratik olarak karar vermesini tercih eden astların oranından oluşmaktadır (Hofstede, 1983a: 50). Hofstede (1983a: 51)'e göre, amirlerin astlarına karşı yüksek güç mesafesi gösterdiği durumlarda astlar da onlara bağımlılık gösteren ve göstermeyen olarak iki kutba ayrılma eğilimindedir. Buna karşın, düşük güç mesafesi uyguladığında ise amirler astları ile konuşarak, onlara danışarak kararlarını vermekte ve ilişki karşılıklı dayanışma ve karşılıklı bağımlılık ilişkisi şeklinde gelişmektedir (Hofstede (1983a: 51).

Hofstede (1983a: 60), yüksek güç mesafesinin anlamını şu şekilde açıklamaktadır,

"Eşitsizlikte herkesin hakl yerinin olduğu bir düzen bulunur ve düzen tarafindan yer yüksek veya düşük olarak korunur. Çok az kişi bağımsız olmall, pek çoğu bağımlı olmalıdır. Üstler, astların kendilerinden farklı olduğunu düşünür. Astlar, üstlerinin kendilerinden farklı olduğunu düşünür. Güç, toplumun temel gerçeğidir, iyi ve kötüden önce gelir. Güç sahibi olanlar, ayrıcalıklara yetkilidir, meşru olup olmaması önemli değildir. Güçlü kişiler, mümkün olduğunca güçlü görünmeye çalışmalıdır. Kötüye giden şeylerde suçlanacak olanlar güçsüzlerdir. Sosyal sistemi değiştirmenin yolu güçlüleri tahttan indirmektir. Diğer kişiler bir kişinin gücüne potansiyel tehdittir ve güvenilemez. Güçlüler ve güçsüzler arasında gizli bir çatışma vardır. Güçsüzler arasında işbirliği zordur çünkü insanlara az güvenmek bir normdur"

Güç mesafesi, bir toplumda gücün kurumlar ve örgütlerde eşit olmamasının kabullenilebilir olup olmamasının hangi aralıkta olduğunun ölçümü olarak tanımlanabilmektedir (Hofstede, 1985: 347). Başka bir ifadeyle, yüksek ve düşük güç mesafeli toplumlar arasındaki temel fark, gücün eşit olmayan bir şekilde dağılımı değil, gücün eşit olmayan şekilde dağılımına toplumun nasıl baktı̆̆ıdır, güç mesafesi oldukça düşük olan bir ülkede bile ülkenin kurumları içinde eşitsizlik derecesi yüksek olabilmektedir (Zhang vd., 2010: 945). Güç mesafesi ile birlikte insanların eşit olmaması, biyolojik farklılıklar dolayısıyla dayanıkl11ık farklıl1kları, yetenekler dolayısıyla sosyal farklılıklar, güç ve zenginlik farklılıkları toplumsal sorunlar olarak ortaya çıkabilmektedir (Hofstede, 1983a: 64). Güç mesafesi ile ilgili olarak toplumun sorunu eşitsizlikle nasıl mücadele ettiğidir (Hofstede, 1983b: 81). Ayrıca, insanlar fiziksel ve zihinsel kapasiteler yönünden eşit değildir ancak bazı toplumlar bu eşitsizlikleri güç ve zenginlikte eşitsizlik haline dönüştürüp daha 
sonra da bunu kalıtımsal olarak yeni nesillere aktarabilirler, hiç bir toplumdaki bireyler birbirine eşit değildir ancak bazı toplumlardaki eşitsizlik daha fazladır (Hofstede, 1983b: 81). Bu sebepten dolayı, gücün eşit olarak dağıtılmadığı toplumlar bu şekilde hayatlarını sürdürebilir çünkü güçsüz olanların bağımlılık ihtiyacı bu şekilde karşılanıyor olabilir, toplumlar ve örgütler, orada bulunan kişilerin izin verdiği ölçüde otokratik yönetim sergileyebilirler (Hofstede, 1983b: 81). Güç mesafesinin yüksek olması durumunda toplumda, yasaklanmış olan cezbedicilere karşı öz-denetim daha fazla görülür, öz denetim, yüksek güç mesafesi ile birlikte gerçekleştiğinde bir kişinin tepkisel olarak hareket etme olasılığı azalacaktır (Zhang vd., 2010: 945).

\section{3. Örgütsel Güç ve Güç Mesafesi}

Örgütler için güç, kritik belirsizlikler ve örgütlerin karşı karşıya kaldığı problemler tarafindan belirlenmekte ve güç örgütteki kararları etkilemektedir (Salancik ve Pfeffer, 1977:5). Örgütlerde gücün kullanımını kıtlık, kritik öneme sahip olmak ve belirsizlik etkilemektedir (Salancik ve Pfeffer, 1977: 13). Diğer yandan Krackhardt (1990: 344)'a göre ise örgütlerde güç temeli, direnç olmasına rağmen istediklerini yaptırabilme ve diğerlerini etkileme olmak üzere iki temele dayanmaktadır. Buna ilaveten, örgütte hem yapısal hem de bilişsel güç kaynakları mevcuttur; resmi yapı, dışsal bir kaynak olarak gayri resmi yapıya, bilişsel doğruluğa ve güce yol açarken, gayri resmi yapı da bilişsel doğruluk ve güce neden olabilmektedir (Krackhardt, 1990: 345-346). Bu nedenle güç, örgütsel çıktıları açılamakta önemlidir (Koslowsky vd., 2001: 455).

Örgütlerde güç, sadece örgütteki anahtar grupların hayatta kalmasını değil aynı zamanda lider pozisyona seçimi ve böylece örgütün çevreye uyumunu sağlamaktadır (Salancik ve Pfeffer, 1977: 14). Bu sebepten dolayı örgütsel güç, çevreye uygun olarak anahtar pozisyonları doldurmaya çalışırken bir yandan da gücü elinde bulunduranlar onu bırakmak istemediklerinden değişim ve durağanlık aynı mekanizma içinde gerçekleşmektedir (Salancik ve Pfeffer, 1977: 17). Buna ilaveten, güç sahibi olanlar sadece pasif olarak hedefleri gerçekleştirmemekte, aynı zamanda hedefleri de belirlemekte, bu sayede de örgütün hedeflerini kendi hedefleri görerek içselleştirmektedir Overbeck ve Park (2006: 240).

Milli kültürün yani örgütün içinde yerleşik bulunduğu kültürün, örgüte aynı şekilde mi yansıyacağı, yoksa örgütün yapısına, şekillenmesine, örgütün çalışanlarına veya liderine göre mi farklılık göstereceği sorusu akla gelmektedir. Hofstede (1983b: 75-76)'e göre örgüt biliminde en önemli etmenlerden biri milli kültürün örgüte nasıl yansıdığıdır. Hofstede, bu durumu şu şekilde açıklamaktadır; milli kültür, bir örgüt için, en başta devletin yapısı, 
eğitim sistemi, vergi mevzuatı, yasal sistem gibi siyasi yön, ikinci olarak, milliyetin vatandaşlar için sembolik bir değeri olması yani sosyolojik yön, üçüncü olarak ise, düşünce tarzının milli kültürle şekillenmesi, okul öncesi ve okul dönemindeki eğitimin milletler arasında farkl1lı göstermesi yani psikolojik yön olmak üzere üç yönden etkilidir (Hofstede, 1983b: 75-76). Netice itibariyle, kültürel değerler örgüt bazında ele alındığında, her örgütün kültürü ve değer sistemi vardır, örgütün kurucusu, yaşadığı toplumun kültürel değerlerini taşımakta ve onu örgüte yansıtmaktadır (Hofstede, 1985: 349). Başka bir deyişle, bir birey kavramları ve düşünceleri yaşadığı toplumdan öğrenmekte, sınırlamalar ve beklenen davranışlara doğrudan veya dolaylı olarak kültür yapısıyla birlikte sahip olmakta ve onları anlam dünyasının bir parçası haline getirmektedir (Zhang vd., 2010: 946). Örgütün faaliyetini sürdürmesinde sembollere istenen anlamın yüklenmesi çok önemli olup örgütte yer alan kişilerin, örgütteki mevki, rütbe, talimatname, ödül, performans gibi sembollere toplumun yüklediği anlamla aynı anlamları yüklediği varsayılmaktadır (Hofstede, 1985: 352). Böylece, sembollere verilen anlam, okul öncesi, okul dönemi ve iş hayatında belirginleştiği için örgütler ve yönetimin her yönüyle milli kültürün etkisi altında (Hofstede, 1983b: 88) olduğu sonucuna ulaşmak mümkündür.

Acaba, örgütün yerleşik olduğu toplumun güç mesafesi, örgüte nasıl yansımaktadır? $\mathrm{Bu}$ soruya yanıt bulmak üzere güç mesafesinin örgütte görünümüne değinilecektir. Örgütlerin yapısı ve işleyiş̧ tarzının şekillenmesinde, güç mesafesi önemli role sahiptir (Hofstede, 1985: 351). Bir örgütün işleyişindeki en önemli etmenlerden biri gücün dağılımını (yetkilendirme, kararları kimin vereceği) şekillendirmektir (Hofstede, 1985: 352). Kısaca ifade etmek gerekirse, örgütün güç mesafesi, merkezileşme derecesi ve otokratik liderlik ile kendini göstermekte, merkezileşme derecesi ve otokratik liderlik güçlü ve güçsüz olanların kültürel değerlerinin bir ürünü olmaktadır (Hofstede, 1983b: 81).

Güç mesafesi, çalışanların örgüte katılımı, çalışanlara yetki verilmesi ve dolayısıyla katılımcı bir örgütün oluşturulması, örgütsel gelişimin sağlanması açısından olumsuz etkilere sahiptir (Ghosh, 2011: 89). Bu etkilerden en önemlisi, güç mesafesinin, astlar ile üstlerin kolayca iletişim kuramaması dolayısıyla astların fikirlerini açıkça ifade edememesidir (Ghosh, 2011: 90). Ayrıca, güç mesafesi yüksek toplumlarda üst yönetimde denetimin ve hesap verirliğin olmaması nedeniyle üst yönetim etik davranmak yönünde üzerinde bask1 hissetmemektedir (Khatri, 2009: 7).

Khatri (2009: 1)'e göre;

“(1) Güç mesafesi yüksek olduğunda çalışanlar kararlarda yer almak istemezler ve yöneticilerin karar vererek onlara pasif olarak uyacakları 
talimat vermesine razı olurlar. (2) Işsler, çalışanlara sınırlı takdir yetkisi verecek şekilde dar ve sıkıca belirlenir. (3) İletişim, yukarıdan aşağıya doğru dikey yönlüdür, yatay iletişim ise çok azdır veya hiç yoktur...(4) Güç mesafesi yöneticilere astları üzerinde sınırsız güç ve denetim verir. Çalışanların ise sorgusuz, itaatkâr tavırları vardır. (5) Yaşlı ve kıdemli çalışanlar genç çalışanlardan yetkinlikleri yüzünden değil, yaşları ve örgütteki uzun kıdemleri yüzünden saygl görürler. (6) Güç mesafesi yüksek kültürde kararlar üst yönetimdeki bir kaç kişi tarafindan despot bir şekilde alınır...(7) Güç mesafesi yüksek olan örgütler etik olmayan davranışa eğilimlidir. Bunun nedeni, üst düzey yöneticilerin alt düzey çalışanlara veya örgüte kararlarını ispat etmek veya savunmak zorunda olmamasıdır. Etik olmayan davranışlar ya fark edilmez veya üstü kapatılır. (8) Güç mesafesi yüksek olan örgütte yöneticiler çok yakından idare ve kontrol eder ve en küçük kararlar bile üst yönetime gider. Böylece, yüksek düzey yöneticiler rutin kararlarla boğulur"

Sonuç olarak, örgüt kültürünün milli kültürün etkisi altında olduğu, milli kültürün değerlerinin örgütte aynı şekilde görüldüğü söylenebilir. Güç mesafesi yüksek olan bir örgüt ele alındığında, örgütte yöneticiler ve astlar arasında mesafe olduğu, astların kendini yöneticilerden farklı hissettiği, kendilerini onlara eşit görmediği, eşitsizliği kabul ettiği ve bu nedenle de itaatkâr ve boyun eğen davranış gösterdiği anlaşılmaktadır.

Örgütler güç, statü ve saygınlık yönünden farklılık gösteren grup içi ilişkilerden oluşan karmaşık ağlar içinde yapılanmıştır (Hogg ve Terry, 2000: 121). Gruplar, toplumsal yaşamın her alanında görülebileceği gibi, örgüt içinde de görülmektedir. $\mathrm{Bu}$ nedenle çalışmanın bu aşamasında grup oluşumu konusuna değinilerek, örgüt içindeki grupların gücünden bahsedilecektir.

\section{Grubun Gücü, Grupta Güç Mesafesi}

Öncelikle, grubun ne ifade ettiği ve grupların oluşma nedenine farklı açılardan bakılmaya çalışılacaktır. Grup, kendilerini aynı sosyal sınıfta algılayan, bu ortak tanımlama içinde duygusal bağlılık yaşayan, sosyal uzlaşmaya sahip bireylerin bir araya gelmesi olarak tanımlanmaktadır (Tajfel ve Turner, 1979: 40). Bireyler belli bir bağlamda grup üyeliğini benimsediğinde, grubun diğer üyeleri ile paylaşma, onlarla uzlaşmaya varma ve davranışlarını o kimliğe uygun olarak yöneltme eğilimi içinde olmakta, grup içindeki diğer üyeleri kendilerine benzer bulmakta ve grup için neyin uygun olduğu, neyin uygun olmadığını, yani normları geliştirmekte ve ortak görüşleri yönünde hareket etmektedir (Haslam vd., 2012: 206). Dolayısıyla, grup oluşumu ile birlikte bireyler grup tarafından belirlenen davranış şekillerine, grubun ortaklaşa düşünce tarzına uygun olarak hareket etmektedir. 
Bireyin birey kimliğinden grup üyesi veya bir sınıfın üyesi olma konumuna geçmesine, sosyal sınıflama kuramı tarafindan açıklama getirilmektedir. Sosyal sınıflama, sosyal çevreyi bölen, sınıflayan, düzen veren ve böylece bireyin sosyal eylemde yer almasına olanak sağlayan bilişsel bir araçtır (Tajfel ve Turner, 1979: 40). Sosyal sınıflama ile birlikte, benlik, bir grup ile değer kazandığında, aynı zamanda kimlikler de grup ile bütünlük kazanmaktadır (Voci, 2006: 74). Başka bir deyişle, birey kendisini ve diğerlerini sosyal sınıf sistemi içindeki yerine, özellikle sosyal grup üyeliğine göre tanımlamakta ve sosyal kimlik, böyle bir sistemde bireyin kendi yerini tanımlaması ile anlaşılabilmektedir (Turner,1975: 7). Bu sayede, sosyal girdiler ile sınıflandırma özelliklerinin uyum içinde olması grup oluşumunda önemli unsurlardan biri olarak yerini bulmaktadır (Voci, 2006: 74).

Sosyal Sinıflama Kuramına göre birey, kendini birey yerine bir grubun üyesi olarak tanımlamakta ve belli bir bağlamda benlik duygusunu hangi grup üyeliğinin verdiğini belirlemeye çalışmaktadır (Haslam vd., 2012: 206). Dolayısıyla, grup içi ve grup dış1 sınıflandırmanın karşılaştırılması, bireysellikten uzaklaşmayı etkilemekte yani grup üyesi olarak kişi benliğini siniflandirmakta ve bu durum grup olgusunu belirlemektedir (Voci, 2006: 75). Anlaşılacağı üzere, sosyal benlik ile bireysel benlik karşılaştırıldığında sosyal benlik uyumu yüksekse benlik algısı bireysellik yitimi ile sonuçlanmaktadır (Voci, 2006: 85). Ayrıca grup davranışının bilişsel temeli olan benlik sinıflaması sonucunda, benlik bilişsel olarak asimile olmakta ve birey, grubun tipik üyesine dönüşmekte (Hogg ve Terry, 2000: 123-124), grup üyeliği daha anlamlı olduğu durumlarda ise (Wyer, 2010: 455) bireysellik yitimi gerçekleşmektedir (Hogg ve Terry, 2000: 123-124; Wyer, 2010: 453). Voci (2006: 86)'e göre grup içi ne kadar homojen ve grup dışından ne kadar farklı olarak algılanırsa bireysellik yitimi o kadar fazla olmakta, bu durumda grup olgusu o kadar güçlü olmaktadır (Voci, 2006: 86).

Sosyal izdüşüm, grup oluşumuna neden olan unsurlardan birisi olarak değerlendirilmektedir. Şöyle ki, sosyal izdüşüm, dışarıdan bakanların, başkalarını, kendilerini gördükleri gibi görme (Leikas vd., 2013: 157) başkalarının kendisi gibi olmasını bekleme eğilimi olarak tanımlanabilmektedir (Robbins ve Krueger, 2005: 32,42). Sosyal izdüşüm, benzerlik varsayımına, dolayısıyla bağlılık algısına, diğer grup üyelerinin çekiciliğine ve nihayetinde gruba bağlanmaya neden olmaktadır (Robbins ve Krueger, 2005: 32,42).

Sonuçta grup üyeliği ile birlikte gruba bağlanma açıkça ortaya çıktığında kişiler bağımsız bireyler olarak değil grup üyesi olarak davranmaya başlamakta (Voci, 2006: 74), sosyal kimlik öne çıktığında bireyler kendilerini diğer grup üyeleri ile yer değiştirilebilir olarak görmekte ve bireysel kimlikleri grup kimliğine doğru kaymaktadır (Wyer, 2010: 453). Sosyal kimlik açısından, grup 
karş1laştırmalarının önemli boyutunun pek çoğu kültürden gelen değerlerle bağdaşmaktadır (Turner,1975: 8).

Grup, kültürel değerlerin etkisi altında ise güç ve güç mesafesinin gruba etkisine bakmak gerekecektir. Çalışmanın bu aşamasında, gücün ve güç mesafesinin gruplara etkisi ve grubun gücüne değinilecektir.

Smith vd. (2001: 340), başkalarına değer biçme olasıllğı, başkaları tarafından değerlendirme olasılığından daha yüksek olan grupları, daha güçlü veya hâkim grup olarak tanımlamaktadır. Örgütte bir grubun gücü, başkaları tarafindan talep edilen eylemleri grubun yapma veya yapmama yetisi olarak tanımlanmaktadır (Salancik ve Pfeffer, 1977: 7). Başka bir ifadeyle, grup, diğer birey veya grupların talep ettiği eylemleri gerçekleştirmiyorsa, bu durum grubun güçlü olduğu anlamına gelecektir.

Sachdev ve Bourhis (1991: 22)'e göre grupla kimlik kazanma derecesinden bağımsız olarak grubun gücü, grup üyelerinin davranış seçeneklerini etkilemektedir. Grup üyelerinin grup içi davranışları ve algılarında grubun gücüne ilave olarak statü ve grup üye sayısı da hem birbirinden bağımsız olarak hem de birlikte güçlü etkiye sahiptir (Sachdev ve Bourhis, 1991: 18). Üç olguyu karşılaştırmak gerekirse, grup içi davranışlarda güç farklılıkları, statü farklılı̆g 1 veya grup sayısına oranla daha fazla etkili olmaktadır (Sachdev ve Bourhis, 1991: 21). Benzer şekilde, grup liderleri, etkileşim sonucu ortaya çıkmakta, kaynaklar bireyler ve gruplar arasında dağıtılmakta, pozisyonlar ve rolleri elinde tutanlara farklı güç kaynakları verilmektedir (Magee ve Galinsky, 2008: 352). Örnek vermek gerekirse; grup, bireysel irade göstermeyi yasaklarken, grubun bir üyesinin bu norma karş1 çıkması, o üyenin güçlü olduğu şeklinde algılanabilmekte, herkes çalışırken iradesini kullanarak oturan kişi diğerlerine göre en güçlü pozisyonda olabilmektedir (Magee, 2009: 12).

Diğer yandan Turner (2005: 9), grubun gücüne farklı bir bakış açısı getirmekte, grup oluşumu veya etkinin kaynak bağımlılı̆̆ından farklı olarak, kişiler arası ilişkiler sonucu ortaya çıktı̆̆ını ve bu ilişkilerin gücü oluşturduğunu ifade etmektedir. Turner (2005: 9)'a göre güç, sosyal ve bireysel kimliği şekillendiren grup oluşumu, ortak inanışlar, kuramlar ve değerlerden ortaya çıkmaktadır. Başka bir deyişle, grup oluşumu isteklerini diğerlerinin yerine getirmesini sağlayan ve ortaklaşa etki sağlayan ikna, otorite ve zorlama sonucunda gerçekleşmektedir (Turner, 2005: 9). Dolayısıyla, kişiler diğerlerini ikna, otorite ve zorlama yoluyla etkilemekte ve kontrol altına almakta, bu süreçler grup kimliği ve ondan ortaya çıkan etki süreci ile tanımlanmaktadır (Turner, 2005: 10).

Güç, kalıp yargı ile karar verme eğilimini artırır mı? Sorusuna çalışmanın bu aşamasında yanıt aranacaktır. Kalıp yargılama, hem bireysel hem de grup 
tarafindan uygulanabildiğinden, önce birey açısından daha sonra da grup açısından ele alınacaktır. Gücün bireysel seviyede önemli etkilerinden biri, güç deneyiminin psikolojik olarak insanlarda dönüşüm sağlaması ve bireylerin psikolojik durumunu değiştirmesidir (Johnson ve Lammers, 2012: 329). Diğer kişiler üzerinde güç elde etme, kendisi ve diğerleri üzerinde algı farklılaşmasını (Klocke, 2009: 619), başkaları hakkında izlenim sahibi olmada zararlı etkileri (Goodwin vd., 2000: 251) beraberinde getirmektedir. Böylece güç, bireyin sosyal bilgiye karşı dikkatsiz ve kapalı olmasına, diğer kişilere karşı dikkatin azalmasına yol açmaktadır (Johnson ve Lammers, 2012: 329, 333).

Güçlü kişiler gruplarının temsilcisi olarak davranmakta ve öyle görülmekte, karar verme otoritesine sahip olma, kaynakları ve çıtıları denetleme, onları hem grupta ayrıcalıklı yapmakta hem de grubun adına hareket edeceği beklentisini doğurmaktadır (Overbeck ve Droutman, 2013: 1474). Güçlü kişilerin çoğu zaman hızlı karar alması gerekmekte, bunu yaparken de kendilerini referans almakta, kendi özelliklerini, tavırlarını ve düşüncelerini, eylemleri ve kararlarında kullanmaktadır (Overbeck ve Droutman, 2013: 1474). Ayrıca, güç sahibi olanlar, aldıkları kararı aktarırken kendi isteği gibi değil grubun isteği ve faydası doğrultusunda yaptığını ifade etmektedir (Overbeck ve Droutman, 2013: 1474).

Goodwin vd. (2000: 230)'ne göre, çıktıları rastgele veya savunulamaz bir şekilde dağıtan güçlü kişiler sadece kötü karar almakla kalmaz, bu kararları savunamadıkları bir durumla da karşı karşıya kalabilirler. Bir kişinin sahip olduğu denetim azsa, denetimi altında olanların davranışlarını öngörmek onun için daha önemli hale gelmektedir (Rodríguez-Bailón vd., 2000: 653). Güç, kısıtlara bağlı bilişsel kaynakları azaltmakta ve sonuçta güçlüyü, güçsüzden ayıran düşünce tarzı, hedeflere ulaşmayı engelleyen kısıtlara farkındalığın azlığı ile sonuçlanmaktadır (Whitson vd., 2013: 582).

Güce sahip olanlar kendi yargılarını doğrulamak ve statülerini korumak için olumsuz sonuçlara yol açan kalıp yargı özelliklerine özel ilgi göstermektedir (Rodríguez-Bailón vd., 2000: 652). Başka bir deyişle güç, kalıp yargı veya algı dikkatsizliğine yol açmakta, hedefin bireyselleştirilmesini engellemekte yani hedef, özgün nitelikleri ile görülememekte, sosyal gruplarının özellikleri ile değerlendirilmektedir (Overbeck ve Park, 2006: 230). Milli kalıp yargılar, ulus devletlerin yapısal özellikleri, yetkinlikle ilgili özellikler, hedef ulusun algılanan ekonomik özelliklerini yansıtmaktadır, şöyle ki, hedef kişinin ulus devleti ekonomik olarak güçlüyse kişi de yetkin olarak algılanmaktadır (Poppe ve Linssen, 1999: 97). Buna ilaveten, astlarını kalıp yargılar içine almak, güçlü olanların pozisyonlarıyla birlikte gelen denetim ve yargılamak için tek otorite konumunda olma arzusundan kaynaklanmaktadır (Goodwin vd., 2000: 228). Netice itibariyle, yargılama konusunda kendini yetkili hissetmek, güç sahibi olanların, kalıp yargıları da ihtiva eden kendi 
inanışlarına güvenlerini artırmaktadır (Goodwin vd., 2000: 229). Böylece, güçlü kişiler astlarını ayrı ayrı değerlendirmekten kaçınmakta, astlar hakkında kalıp yargıya uyumlu bilgi, güç kimliğin korunmasını ve desteklenmesini sağlamaktadır (Goodwin vd., 2000: 230).

Kısaca özetlemek gerekirse, gücü elinde bulunduranlar, kısa sürede karar vermeleri gerektiğinden, sosyal bilgiye karşı dikkatsiz ve kapalı olduklarından, hedeflere ulaşmayı engelleyen kısıtlara farkındalıkları az olduğundan, algı dikkatsizliklerinden, kendi inanışlarına olan güvenlerinden ve güç kimliğinin korunmasını ve desteklenmesini arzu ettiklerinden kalıp yargılarla düşünme eğiliminde olmaktadır. Grubun lideri veya güçlü pozisyonunda olan kişiler de kendi kararlarını grubun kararlarıymış gibi yansıtmaktadır.

O halde, güçlü olmanın kalıp yargılama eğilimini artırdığg sonucuna ulaşmak mümkün görülmektedir. Güç mesafesi, gücün dağılımının eşit olmamasını kabullenme, güçlü bireyler tarafından alınan kararların denetlenme ihtimalinin azlığı anlamını taşıyacağından güç mesafesi yüksek toplumlarda kalıp yargılama eğiliminin daha fazla olacağından söz edilebilir.

\section{Önerme 1: Güç mesafesi yüksek toplumlarda, güç sahibi olanların kalıp yargılarla karar verme eğiliminin fazla olmast beklenebilir.}

Şimdi de kalıp yargılar ve önyargılar grup açısından ele alınacaktır. Hogg ve Terry (2000: 123-124)'e göre, bireysellikten iç grup üyeliğine geçişle birlikte grup içi davranışlar, biçimsel davranışlar, kalıp yargı, grup içi bağlılık, işbirliği ve grup üyelerine maddi manevi çıkar gözetmeksizin faydalı olmaya çalışma, empati, topluca davranış, ortak normlar ve karşılıklı etki görülmektedir. Öte yandan, ödülün tahsisi, grubun değerlendirmesi veya grubun ürününün değerlendirmesi söz konusu olduğu durumlarda, etkileşim ve davranışların etkisiyle birlikte grup içi önyargılar ortaya çıkmaktadır (Turner, 1975: 32). Kişiler grubun kalıp yarg1 özelliklerini, grubu temsil eden davranışları grubun tipik üyesi olarak gerçekleştirmekte, grubun tipik üyeleri yoluyla grup, diğer gruplardan inanış, tavır, duygu, davranış yönünden ayrılmakta ve bu sayede iç grup benzerliği, dış grup farklılığı oluşmaktadır (Hogg ve Terry, 2000: 123-124). Böylece, bireyler benzer oldukları grupları ile uzlaşma içinde olduklarını göstermek istediklerinden, grupları için biçimsel gördüklerine ve gruplarının kalıp yargılarına tam olarak uyum göstermektedir (Hogg vd., 1990: 79). Ayrıca, duygular yargılama yanlışlıklarında ve genel olarak grup dinamiklerinde rol oynadığından, daha güçlü grubun üyeleri karşı tarafı kalıp yargılarken, daha az güçlü grubun üyeleri karşı tarafı daha doğru yargılama eğiliminde olmaktadır (Ebenbach ve Keltner, 1998: 8,18). İlave 
olarak, Levin vd. (2002: 145)'ne göre grup içi önyargılar grup içindeki statüye göre de farkl1lıklar göstermekte, grup içi önyargılar hiyerarşinin devam etmesi yönünde de eğilim göstermektedir.

Bireyler, sosyal kimliklerini grupla birlikte edinmeleri durumunda, grupları için biçimsel gördüklerine ve gruplarının kalıp yargılarına, grup önyargılarına uyum gösterme eğilimi içinde olmaktadır. Ayrıca, grup içi önyargılar hiyerarşinin devam etmesi yönünde de eğilim gösterebilmektedir. Güç mesafesi yüksek olan toplumlarda, güce karşı boyun eğme, güce itaat etme eğilimi yüksek olduğundan ve eşitsizliği kabullenmenin de etkisiyle hem grubun güçlü üyelerine itaat etme, hem de hiyerarşinin devam etmesi isteği dolayısıyla grup içi önyargıların ve grup dışına karşı önyargıların fazla olması beklenebilir.

\section{Önerme 2: Güç mesafesi yüksek toplumlarda, grup kalıp yargılarının ve grup içi önyargıların daha fazla olması beklenebilir. $\mathrm{Bu}$ eğilim, güçlï gruplarda daha fazla görülebilir.}

\section{Grup İçi - Grup Dışı Kayırmacılık}

Grup içi önyargılar, ait olduğu grup için pozitif ayrımcılık elde etme çabasından kaynaklanmakta, grup içi karşılaştırmalar sonucu grup kayrılırsa olumlu sosyal kimlik görülmektedir (Levin vd., 2002: 144). Ayrıca, grup içi önyargılar farklı gruplar içinde kaynakların dağıtılması gibi pek çok konuda kararlar1 etkilemektedir (Levin vd., 2002: 144). Buna ilaveten, gruplar arası önyargı, bir kişinin sistematik bir şekilde kendi grubunu, farklı gruplara karşı tercih edecek şekilde değerlendirme yapması olarak tanımlanmakta, gruba hizmet etme eğilimi, grup içi kayırmacılık veya grup dışını kötüleme şeklinde kendini göstermektedir (Hewstone vd., 2002: 576). Netice olarak gruplar aras önyargılar, grup özellikleri (kalıp yargılar), kendi grubuna farklı davranma veya dış grup üyelerine farklı davranma (ayrımcılık) şeklinde kendini göstermektedir (Hewstone vd., 2002: 576-577).

Tajfel ve Turner (1979: 41)'a göre, gruplar benzerlik, yakınlık, durumsal dikkat çekicilik gibi özelliklerini grup dışı ile karşılaştırmaktadır. $\mathrm{Bu}$ karşılaştırma sonucu, dış gruba karşı üstünlük sağlamak üzere, gruplar dış gruba göre farklılaşmak istemektedir (Tajfel ve Turner, 1979: 41). Bir grubun özelliklerini, onun normlarını ve kalıp yargılarını tanımlamak, grubu diğer dış gruplardan ayırmak suretiyle grup ile dış grubun farklılı̆̆ını en üst seviyeye çıkarmaktadır (Hogg vd., 1990: 80). Gruplar diğer gruplardan farklılaşmak isterken, grupla birlikte bireysellik yitimi de grup içi kayırmacılık, grup içi bağlılık ve grup içi işbirliği gibi tipik davranışlara neden olmaktadır (Voci, 
2006: 85). Ayrıca, seçenekler, eşitlik stratejisinden uzaklaştığında grup içine fayda sağlama eğilimi yani grup içi kayırmacılık görülmektedir (Turner,1975: 14). Grup içi kayırmacılık ve grup dışına karşı farklılığın fazla olduğu durumda, grup daha fazla ayrımcılık göstermekte ve dışarıya karşı daha az adil olmaktadır (Tajfel ve Turner, 1979: 42).

Sonuç olarak, grup içi kayırmacılık, kendi grubunda olanlara ayrıcalık tanıma, kendi grubuna pozitif ayrımcıllk yapma ve grup üyelerine maddi veya manevi çıkar gözetmeksizin faydalı olmaya çalışma olarak tanımlanabilir. Bireylerin sosyal kimlikleri, bir grubun üyesi olmaları, gruba ait olmaları dolayısıyla bireysellik yitimi göstermelerinin grup içi kayırmacılık eğiliminde etkili olduğu anlaşılmaktadır. Ayrıca, grup içi ve gruplar arası önyargılar, kalıp yargılar, grup içi kayırmacılığa neden olmaktadır. Eşitlik stratejisinden uzaklaşıldığında grup içine fayda sağlama eğilimi yani grup içi kayırmacılık görülmektedir. Grup içi kayırmacılık ve grup dışına karşı farklılığın fazla olduğu durumda, grup daha fazla ayrımcılık göstermekte ve dışarıya karşı daha az adil olmaktadır. Demek oluyor ki, eşitsizlik kabullenildiğinde, daha fazla grup içi kayırmacılık beklemek yanlış olmayabilir.

\section{Önerme 3: Güç mesafesi yüksek toplumlarda, grup kalıp yargılarının ve grup içi önyargıların da etkisiyle grup içi kayırmacılık eğilimi artabilir.}

Grup kimliği dışında, gruplar arası güç ve statü farklılığının kayırmacılığa etkisine bakmak gerekirse, Dasgupta (2004: 148) insanların tavır, davranış ve inanışları ile grup içi kayırmacılık yapma eğiliminde olmasına rağmen grup içi ve grup dışı güç ve statü farklılıklarının da insanların davranışlarını şekillendirdiğini öne sürmüştür.

Sosyal kimlik kuramına göre bireyler, üyesi oldukları grup aracılığıyla benlik saygısını koruma ve geliştirme gereksinimlerini karşılamak üzere diğer gruplarla kıyasladığında, kendi gruplarını olumlu değerlendirmekte yani kayırmaktadır. Ancak, iç grubun koşulları olumsuz olduğunda bireyler kimliğini geliştirmek için üç yol izlemektedir; birinci yol, grubundan ayrılarak, yüksek statülü gruba geçmeye çalışmak, ikinci yol, sosyal rekabet yoluyla yüksek statülü grubun üstünlüğüne meydan okumak, üçüncü yol ise sosyal yaratıc1lık yoluyla grup içine uygun yollarla sosyal karşılaştırma firsatları elde etmektir (Overbeck vd., 2004: 37). Ayrıca bu kuram, algılanan statü farklılı̆̆ 1 arttıkça, eşitsizliğe meydan okunması ile birlikte grup içi kayırmacılığın artmasını öngörmektedir (Overbeck vd., 2004: 38). İlave olarak, meşruiyet ve yapısal kararlılık da düşük statülü grubun davranışlarını belirlemektedir (Overbeck vd., 2004: 37). 
Sosyal Baskınlık Kuramına göre büyük çaplı sosyal sistemler, hiyerarşi ve sosyal yapılandırılmış gruplarla, bir ya da daha fazla gruba daha fazla güç ve statü tanıma eğilimindedir (Levin vd., 2002: 145). Ayrıca, sosyal hiyerarşi, güç eşitsizliği, kayırmacılık ve ayrımcılı̆̆ın başlaması ve korunmasına katkı sağlamaktadır (Rosenblatt, 2012: 237-238). Sözü edilen kuram, gruba dayalı sosyal hiyerarşinin, kümelenmiş bireysel ve kurumsal ayrımcılık ile meşrulaştırma mitleri tarafından düzenlenen davranışsal asimetri süreçleri sonucu oluştuğunu savunmaktadır (Sidanius ve Pratto, 2004: 426).

Sosyal Baskınlık Kuramına göre, çoğunluğun üyeleri kendi gruplarının üstün konumunu, meşrulaştırma mitleri ile sağlamaya ve savunmaya çalışmaktadır (Hindriks vd., 2014: 538). Diğer bir ifadeyle, bireylerin meşrulaştırma mitlerine karşı tutumu, gruba dayalı sosyal hiyerarşi sistemini destekleyip desteklemediğini göstermektedir (Sidanius ve Pratto, 2004: 426). Dolayısıyla, gruba dayalı sosyal hiyerarşi, sosyal sistem içinde sosyal değeri yansıtan, ahlaki ve düşünsel yönden meşrulaştırmayı sağlayan, tavırlar, değerler, inanışlar, kalıp yargılar ve ideolojiler gibi meşrulaştırma mitlerinden etkilenmektedir (Sidanius ve Pratto, 2004: 431).

Meşrulaştırma mitleri işlevselliği ve etkisine göre ikiye ayrılmakta, işlevsel mitler, hiyerarşiyi artırıcı ve azaltıcı olmak üzere iki grupta incelenmekte, mitin etkisi ise gruba dayalı hiyerarşinin ilerlemesi, kalıcılığ 1 ve kaybolmasının derecesini göstermektedir (Sidanius ve Pratto, 2004: 431-432). Irkçılık, cinsiyet ve sınıf ayrımcılığı, hiyerarşiyi artırıcı meşrulaştırma mitleri içinde yer alırken, sosyalizm, komünizm, feminizm, insan hakları gibi siyasi doktrinler, hiyerarşiyi azaltıcı mitler içinde yer almaktadır (Sidanius ve Pratto, 2004: 432).

Sosyal güce bağlı olarak davranışlarda farklılık görülebilmekte, davranışlar, sosyalleşme örüntüsü, kalıp yargılar, meşrulaştırma ideolojileri ve eğilimlerden etkilenmektedir (Sidanius ve Pratto, 2004: 429). Böylece gerçekleşen davranışsal asimetri, ortaklaşa gruplar arası baskı ve gruba dayalı sosyal hiyerarşiye neden olmakta, grup içi önyargılar, grup dışı kayırmacılık ve ideolojik asimetri şeklinde kendini göstermektedir (Sidanius ve Pratto, 2004: 430).

Sosyal Baskınlık Kuramına göre Sosyal Baskınlık Yönelimi (SBY) fazla olan bireyler, gruplar arası hiyerarşinin artmasını ve kendi gruplarının diğer gruplara karşı baskın olmasını isterler (Hewstone vd., 2002: 583). SBY, sosyal ilişkilerde eşitsizliğin tercih edilmesi olarak anlam bulmuştur (Jost ve Thompson, 2000: 210-211). SBY, düşük statülü grup için, sistem meşru görüldüğünde yüksek statülü gruba kayırmacılık ile ilişkilidir (Levin vd., 2002: 147). Bununla birlikte, meşru norm, inanış ve değerler bireysel tutum ve davranışları, kurumların işleyişini ve sosyal uygulamaları şekillendirmekte, 
bunlar arasında kurumlar gibi hiyerarşi sağlayıcılar ile grup temelli eşitsizliğe yol açanlar (örneğin, güç mesafesi değeri) yer almaktadır (Rosenblatt, 2012: 240). Ayrıca, sosyal hiyerarşi, eşitsizliğin bireysel ve kurumsal olarak onaylanması ile bu olguları destekleyici süreçler, güç ve pozisyonların kötüye kullanılmasına karşı farkındalığı azaltmaktadır (Rosenblatt, 2012: 241).

Diğer yandan, sistemi meşrulaştırma kuramı ise ayrımcılığı, benliği, grubu ve sistemi meşrulaştırma yönüyle tanımlamaktadır (Rubin ve Hewstone, 2004: 839). Bu kuram, düşük statülü grubun üyeleri tarafından gösterilen grup dışı kayırmacılığın sistemi meşrulaştırmayı açıkladığını vurgulamaktadır (Rubin ve Hewstone, 2004: 834). Ayrica, düşük statülü grup üyeleri, sosyal sistemin bilincinde olma ve ona uyum sağlamaktan öte, sosyal sistemi aktif bir şekilde meşrulaştırma, istikrarını sağlama, kayırma, destekleme ve savunma davranışları göstermektedir (Rubin ve Hewstone, 2004: 834). Buna ilaveten, alt grubun üyeleri hayattaki yerlerini kabul eder gibi görünmenin aksine, kendilerini baskın kültürün bakışıyla görmektedir (Jost vd., 2002: 589). Sistemi meşrulaş̧ırma kuramı, sosyal kimlik, grup merkeziyetçiliği ve benzerliği üzerine kurulmakta, bireylerin bilinçli veya bilinçsiz bir şekilde sosyal sistemi meşrulaştırdığını ve devamını sağlamaya çalıştığını savunmaktadır (Jost vd., 2002: 587). Bu kurama göre, bilişsel, güdüsel ve sosyal etmenler sosyal sistemi açıklama ve meşrulaştırmaya yol açmaktadır (Jost vd., 2002: 587).

Sonuç olarak, düşük statülü grubun üyeleri öz saygının korunması (Dasgupta, 2004: 148) gibi statü farklılığı ile daha az ilişkili veya ilgisiz boyutlarda grup içi kayırmacılık (Poppe ve Linssen, 1999: 88; Overbeck vd., 2004: 37), daha alt seviyede olmaları sistemden kaynaklandığında ise grup dışı kayırmacılık göstermektedir (Overbeck vd., 2004: 37; Poppe ve Linssen, 1999: 88; Dasgupta, 2004: 162-163). Düşük statülü gruplar, statükoyu gerçekleme yönelimlerinden dolayı grup dışı kayırmacılık göstermekte, düşük ve yüksek statülü grup arasında algılanan statü farklılığı arttıkça düşük statülü grubun kabullenici karşılık vermesi, grup dışı kayırmacılığa yol açmaktadır (Overbeck vd., 2004: 38). Sözü edilen grup dış1 kayırmacılık, grup üyelerinin sayısı veya güçleri yönünden düşük statü pozisyonlarını giderecek bir yön olmadığında görülmektedir (Sachdev ve Bourhis, 1991: 19).

Öte yandan, yüksek statülü grup üyeleri, düşük statülü grup üyelerine göre daha çok ayrımcı ve daha az eşitlik yönelimli davranış göstermektedir (Sachdev ve Bourhis, 1991: 18). Yüksek statülü grubun üyeleri kendi gruplarına statü farklılığının yansıtacak üstünlük atfetmektedir (Poppe ve Linssen, 1999: 88). Ayrıca, yüksek statülü grubun üyeleri kendi gruplarına karşı kayırmacılığ ve belirgin dış gruplara karşı önyargıları, düşük statülü gruplara kıyasla daha çok göstermektedir (Dasgupta, 2004: 162-163). Dasgupta (2004: 148) bu durumun nedenini, mevcut sosyal hiyerarşinin devam etmesi isteğine 
bağlamaktadır. Netice itibariyle grup içi kayırmacılık, gruplar arası ayrımcılık olarak davranışa dönüşmektedir (Robbins ve Krueger, 2005: 43).

Özetle, Sosyal Kimlik Kuramı, algılanan statü farklılığı arttıkça, eşitsizliğe meydan okunması ile birlikte grup içi kayırmacılı̆̆ın artmasını öngörmektedir. Diğer yandan, Sosyal Baskınlık Kuramına göre sosyal sistemler, hiyerarşi ve sosyal yapılandırılmış gruplarla, bir ya da daha fazla gruba daha fazla güç ve statü tanıma eğilimindedir. Ayrıca bu kuram, gruba dayalı sosyal hiyerarşinin, bireysel ve kurumsal ayrımcılık ile meşrulaştırma mitleri tarafindan düzenlenen davranışsal asimetri süreçleri sonucu oluştuğunu savunmaktadır. Netice itibariyle sosyal hiyerarşi güç eşitsizliği, kayırmacılık ve ayrımcılığın başlaması ve korunmasına katkı sağlamaktadır. Sistemi meşrulaştırma kuramı ise, düşük statülü grubun üyeleri tarafindan gösterilen grup dışı kayırmacıllı̆ı̆ sistemi meşrulaştırmaya yönelik olduğunu vurgulamaktadır. Yüksek statülü grubun üyeleri kayırmacılığı ve belirgin önyargıları, düşük statülü gruplara kıyasla daha çok göstermektedir. İlave olarak, kurumların işleyişini ve sosyal uygulamaları şekillendiren değerler arasında "güç mesafesi" yer almaktadır. Son olarak da, sosyal hiyerarşi ile eşitsizliğin bireysel ve kurumsal olarak onaylanması güç ve pozisyonların kötüye kullanılma farkındalığını azaltmaktadır.

Güç mesafesi değeri eşitsizliğin kültür değeri olarak kabullenilmesi ve onaylanması anlamı taşıdığından ve böylece gücün kötüye kullanma farkındalığını azalttığından, grupların önyargılarının ve kalıp yargılarının da etkisiyle kayırmacılık göstermesi beklenebilir. İlave olarak bu tutumun hiyerarşinin de etkisiyle yüksek statülü gruplarda, düşük statülü gruplara oranla daha fazla olması mümkün olabilir. Grup içi kayırmacılığın fazla olması eğilimi ile birlikte grup içine kayırmacılık ve fayda sağlanmasının bekleneceği, bu durumun gruplar arası ayrımcılığa neden olabileceği sonucuna varılabilir. Düşük statülü grup için, sistem meşru görüldüğünde yüksek statülü gruba kayırmacılık görüldüğünden, güç mesafesi değeri de eşitsizlik sistemini meşru kıldığından bu durum grup dışı kayırmacılığa neden olabilir.

Önerme 4: Güç mesafesi yüksek toplumlarda, yüksek statülü gruplarda, grup içi kayırmacılı̆̆ın yüksek olması beklenebilir. Grup içi kayırmacılı, gruplar arası ayrımcılı̆ga neden olabilir. Düşük statülü gruplarda ise grup dışı kayırmacılı̆̆ın yüksek olması beklenebilir.

Eşitliğe karşı olan tavırları, pek çok sosyoloji kuramı açılamaya çalışmaktadır (Kugler vd., 2010: 118). SBY, biri Gruba Dayalı Baskınlık (GDB), diğeri Eşitliğe Muhalefet (EM) olmak üzere birbiri ile ilişkili iki 
ideolojik boyuttan oluşmaktadır (Jost ve Thompson, 2000: 209; Hindriks vd., 2014: 539). GDB eğilimi, bazı grupların diğer gruplar karşısında aktif bir şekilde boyun eğdirilmesine yönelik olarak baskın hiyerarşiyi destekleyici biliş, tavır ve davranışları içermektedir (Ho vd., 2012: 585). Bu nedenle GDB, daha çok dış gruba karşı olumsuz duygular, düşmanca rekabet, kalıp yargıları kullanma eğiliminden dolayı bireysel farklılıklar ile ilgilidir (Kugler vd., 2010: 118). GDB eğilimi yüksek olanlar, gruplar arası hiyerarşiyi artırarak dış gruba baskın olma yönünde güçlü isteğe sahiptir (Rubin ve Hewstone, 2004: 835).

Diğer yandan, EM ise gruba dayalı eşitliğe karşı olmayı, eşitliğin genel prensiplerinden uzaklaşmayı ve sosyal grupların hiyerarşi düzeylerini azaltmayı içermektedir (Ho vd., 2012: 585). Başka bir deyişle EM, evrensellik, insaniyet ve eşitliğe karşı çıkarak, sistemin yaşatılmaya devam etmesi ve mevcut sosyal düzenin değiştirilmesine karşı olmak ile ilgilidir (Kugler vd., 2010:118). Ancak, GDB'den farklı olarak EM, baskıyı veya gruplar arası düşmanlığı desteklememektedir (Ho vd., 2012: 585). EM, düşük statülü gruplarda grup içi kayırmacılık ile olumsuz yönlü ilişkili (Jost ve Thompson, 2000: 230) iken, yüksek statülü gruplarda olumlu yönlü ilişkilidir (Jost ve Thompson, 2000: 230; Levin vd., 2002:146). Zira EM, yüksek statülü gruplarda grup içi kayırmacıllı̆a işaret etmekte, grup içi önyargılar statükoyu ve grup çıkarlarını artırmayı amaçlamaktadır (Levin vd., 2002: 154

GDB eğilimi yüksek olan toplumlarda pek çok meşrulaştırma inanışları ve politik tavırlar, alt grupların baskın gruplar tarafından boyun eğdirilmesi işlevi görmektedir (Ho vd., 2012: 586). Eğer meşrulaştırma miti, bask1 ve zorlamayı amaçlıyorsa GDB, daha gizli bir şekilde eşitsizliği destekliyorsa, EM ile ilgilidir (Ho vd., 2012: 595). Yüksek statülü grup üyeleri için, GDB'nin yüksek olması ve sosyal düzenin değişimine karşı olunması yani EM'nin yüksek olması birbiri ile oldukça uyumludur (Kugler vd., 2010: 119; Levin vd., 2002: 147; Jost ve Thompson, 2000: 229) ve ayrıcalıkların devamı açısından hiyerarşi sisteminin devamı desteklenir (Levin vd., 2002: 147). Nitekim EM, sistemi meşrulaştırmanın ideolojik işlevi olarak hizmet etmektedir (Jost ve Thompson, 2000: 231)

EM, sosyal sınıfın bir özelliğidir ve tepenin tabandan ne kadar uzak olması gerektiği ve tabandakilerin talep ettiği anlayışın derecesi ile ilgilidir (Kugler vd., 2010: 148-149). GDB ve EM tavrı, grup dışında olanlara yardım etme davranışını azaltır, GDB, grup dışında olanları baskı altına alma, EM ise yardım etme motivasyonundan yoksun olma ile ilgilidir (Kugler vd., 2010: 150). Düşük statülü gruplarda EM ve GDB, mevcut hiyerarşik yapının desteklenerek grubun çıkarlarının reddedilmesi ve yüksek statü lehinde grup dışı kayırmacılık ile sonuçlanabilir (Levin vd., 2002: 147). Diğer yandan, GDB eğilimi yüksek olanlar, önyargılarla ilgili hiyerarşiyi artırıcı meşrulaştırma 
mitlerini kullanırken, EM eğilimi yüksek olanlar ise hem hiyerarşiyi artırıcı hem de azaltıcı mitleri kullanmaktadır (Hindriks vd., 2014: 546).

Yinelemek gerekirse GDB, kalıp yargıları kullanma eğiliminden dolayı bireysel farklılıklar ile ilgilidir ve kendi grubunun baskınlığ ise eşitliğe karşı çıkarak, sistemin yaşatılmaya devam etmesi ve mevcut sosyal düzenin değiştirilmesine karşı olmak ile ilgilidir. Yüksek statülü gruplarda EM ile GDB birbiri ile uyumlu olup grup içi kayırmacılığa neden olabilir. Ayrıca, EM, tepenin tabandan ne kadar uzak olması gerektiği ve tabandakilerin talep ettiği anlayışın derecesi ile ilgili olduğundan, güç mesafesi yüksek toplumlarda eşitsizliği kabullenme eğilimi ile birlikte yüksek statülü gruplarda EM olacağı ve kalıp yargıların da etkisiyle GDB'nin yüksek olacağı önerilebilir.

\section{Önerme 5: Güç mesafesi yüksek toplumlarda, yüksek statülü gruplarda EM ve GDB eğilimi, grup içi kayırmacılık ile gruplar arası ayrımcıllğa neden olabilir. Düşük statülü gruplarda ise EM ve GDB eğilimi, grup dışı kayırmacılığa yol açabilir.}

\section{6. Örgüt İçinde Bireylerin Gücü}

Çalışmada şu ana kadar örgütsel ve grubun gücü konuları incelenmiş olup bu aşamada örgütteki bireylerin gücünden, gücün kullanımından yani etkiden söz edilecektir. Klocke (2009: 619-620), güç ve etkinin birbirinden farkını ortaya koyarak, gücü etki yapma kapasitesi, etkiyi gücün fiili olarak kullanılabilmesi olarak tanımlamıştır. Yazara göre etki, davranışsal taktikler açısından sınıflandırılmakta, güç ise sahip olduğu temel açısından sınıflandırılmaktadır. Zira, gücün, davranışa dönüşmüş şekli etki olarak nitelendirilmektedir. Gücü elinde bulundurmaya temel teşkil eden güç kaynakları ile etki taktikleri yani gücü kullanma taktikleri birbirinden ayrılmaktadır (Koslowsky vd., 2001: 457). Güç kaynakları ile etki taktikleri arasındaki temek fark, etki olarak uygulanmadığında bile güç kaynaklarına astların itaat edebilmesidir (Koslowsky vd., 2001: 457). Koslowsky vd. (2001: 457) güç kaynaklarını yumuşak güç kaynakları ve sert güç kaynakları olarak iki başlık altına toplamış, yumuşak güç kaynaklarını, uzmanlık, başvuru, bilgi, bağımlılık meşruiyeti olarak sıralamıştır. Aynı yazarlar sert güç kaynaklarını ise şahsi ve gayri şahsi zorlama, şahsi ve gayri şahsi ödül, pozisyonun meşruiyeti ve karşılıklılığın meşruiyeti olarak adlandırmıştır. Öte yandan Klocke (2009: 619-620), gücün iki tabanı olduğunu, bunlardan ilkinin bilgi ve yeteneğe dayalı olan uzmanlık gücü, diğerinin ise etkiyi resmi kurallarla meşru hale getiren pozisyon gücü olduğunu vurgulamaktadır. Uzmanlık gücü bireysel çaba sonucu elde edilebilecekken pozisyon gücü, örgüt veya diğer otorite kaynakları tarafından bahşedilmektedir (Ayman vd., 1995: 156). Anlaşılacağı üzere, örgüt 
içinde bireysel güç, bireyin görev aldığı pozisyon dolayısıyla elde edilebileceği gibi bireyin yaptığı işte uzman olması dolayısıyla da elde edilebilir.

Güç mesafesi, bireyin pozisyon otoritesinden değil de işlevsel otoritesinden yani uzmanlığından kaynaklanıyorsa bu durumda gücün kaynağ 1 bireyin bilgi, beceri ve kazanımları olduğundan, yasal, ussal hiyerarşiden bağımsızdır (Ghosh, 2011: 95). Dolayısıyla, hiyerarşi, uzmanlık gücü gibi bireysel özellikler dolayısıyla şekilleniyorsa, bireyler işlevsel güçlerini artırma eğilimi gösterecektir (Ghosh, 2011: 95).

Etki açısından ele alındığında; sert etki taktikleri, baskı, iddiacılık, koalisyon, meşrulaştırma ve engel olma, yumuşak etki taktikleri ise ussal ikna, ilham verici kurullar, kendini kabul ettirme ve danışmanlık olarak tanımlanmaktadır (Klocke, 2009: 619-620). Sert etki taktikleri, etki aktörünün, örgütteki pozisyonundan kaynaklanmakta ve bu kaynakların kullanımının görevle ilgisi daha az olmaktadır (Koslowsky vd., 2001: 470). Bu durumda, karşıdaki kişi, itaat için pozisyon avantajının kullanıldığını algılamaktadır. Bunun aksine, bilgi ve deneyim gibi yumuşak kaynaklar daha çok işle ilgilidir ve itaat örgütsel kaynaklar ile değil bireysel olarak elde edilmektedir (Koslowsky vd., 2001: 470).

Güç sahibi olanların kendilerini ve hedeflerini değerlendirmeleri, güçlerini nasıl kullandıklarına bağlı olup, pozisyon gücü sert etki taktikleri ile uyumlu iken, uzmanlık gücü yumuşak etki taktikleri ile uyumludur ve pozisyon gücü olanın, uzmanlık gücü olana göre sert etki taktiklerini daha sık kullanması beklenir (Klocke, 2009: 632). Yinelemek gerekirse yöneticiler, güç mesafesi ile birlikte astları üzerinde güç ve denetim uygulama hakkı elde etmekte, çalışanlar ise yöneticilere itaatkâr yaklaşmaktadır (Khatri, 2009: 1).

Netice itibariyle, güç mesafesi yüksek olan toplumlarda astların itaatkâr tavrı olması nedeniyle güçlerini pozisyonundan alan yöneticilerin astlarına güç ve denetim uygulama eğiliminde olabilecekleri değerlendirilebilir. Yukarıda da ifade edildiği üzere, pozisyon gücü sert etki taktikleri ile uyumlu olmasına rağmen uzmanlık gücü yumuşak etki taktikleri ile uyumlu olduğundan, aşağıdaki önermeye ulaşmak mümkün olabilecektir;

Önerme 6: Güç mesafesi yüksek toplumlarda ve toplumun özelliklerini sergileyen örgütlerinde, gü̧̈, hiyerarşiden ve pozisyondan dolayı elde edilmişse güç sahibi olanın sert etki taktikleri uygulaması, güç, teknik bilgi ve uzmanlıktan dolayı elde edilmişse de güç sahibi olanın yumuşak etki taktikleri uygulaması beklenebilir. 


\section{Sonuç}

Sosyal bilimlerin pek çok olgusuna güç ile açılama getirilebilmekte güç, özellikle ilişkinin tarafları arasındaki güç farklılıkları sosyal ilişkileri şekillendirmektedir. Gücün elde edilişi, güce sahip olma potansiyeli farklı nedenlerle oluşsa da en önemli etmenlerden biri kaynaklara sahip olma ve onları yönetme yetisi olarak açılanmaktadır. Buna karşın güç, kaynakların eşit olmayan bir şekilde dağıtımına da yol açabilmektedir. Güçlü olan bireyler, gruplar veya örgütler diğer birey, grup veya örgütlerin çıktılarını denetlerken, diğerlerine olan bağımlılıkları daha az olmaktadır. Güçle birlikte anılan en önemli kavramlardan birisi olan statü ile güç arasındaki temel fark şu şekilde ifade edilebilir; güç, gerek kaynaklar, gerek bağımlılık, gerekse denetim yönünden aktörün sahip olduğu bir özellik iken statü, aktörün içinde bulunduğu ortam veya çevresindeki diğer bireyler tarafından aktöre verilmektedir. Güçle ilgili en önemli sorunlardan birisinin, gücün suistimal ve yozlaşmaya yol açabilmesi olduğu değerlendirilebilir.

Toplumsal kültür çalışmalarının bir boyutu da güç mesafesidir (Hofstede, 1983a: 46). Güç mesafesinin yüksek olması, güçlünün güçsüzden farklı olması, kararların güçlüler tarafından verilmesi, güçlünün ayrıcalıklara sahip olması, toplumda var olan eşitsizliğin taraflar tarafindan kabul edilmesi olarak tarif edilebilir. Bir toplumda yaşayan, varlığını sürdüren bireylerin, grupların ve örgütlerin, toplumun güç mesafesini yansıttığı varsayılmaktadır. Başka bir deyişle, toplumun güç mesafesi yüksekse, bireyler, gruplar ve örgütler de, güç mesafesi yüksek olan toplumun özellikleri doğrultusunda hareket etmektedir.

Güç mesafesi yüksek olan bir toplumda yer alan, dolayısıyla güç mesafesinin yüksek olduğu varsayılan bir örgütte en belirgin özelliklerin; kararların amirler ve üst yönetim tarafından verilmesi, güçlü olanların kendilerini ve aldıkları kararları savunmak zorunda olmamaları nedeniyle etik davranmak yönünden üzerlerinde baskı hissetmemeleri olarak ifade edilebilir. Buna paralel olarak da astların kendini yöneticilerden farklı hissettiği, kendilerini onlara eşit görmediği, eşitsizliği kabul ettiği ve bu nedenle de itaatkâr ve boyun eğen davranış gösterdiği değerlendirilebilir.

Toplumsal yaşamın her alanında görülebilen gruplar, örgüt içinde de görülmekte, grup oluşumu ile birlikte bireyler grup tarafından belirlenen davranış şekillerine, grubun ortaklaşa düşünce tarzına uygun olarak hareket etmektedir. Bireylerin grupları ile kendilerini özdeşleştirme, gruba bağlanma derecelerine bağlı olarak sosyal kimlik öne çıabilmekte, birey kendini birey olarak değil, bir grubun üyesi olarak tanımlamakta, kendini diğer grup üyeleri ile özdeş olarak görebilmektedir. Güç, toplum, birey ve örgütte olduğu gibi grubun davranışlarını da şekillendirmektedir. 
Güçlü olanlar, kararları çoğu zaman hılı bir şekilde almaları gerektiğinden, sosyal bilgiye karşı dikkatsiz ve kapalı olduklarından, hedeflere ulaşmayı engelleyen kısıtlara farkındalıkları az olduğundan, alg1 dikkatsizliklerinden, kendi inanışlarına olan güvenlerinden ve güç kimliğinin korunmasını ve desteklenmesini arzu ettiklerinden kalıp yargılarla düşünme eğiliminde olmaktadır. Grubun lideri veya güçlü pozisyonunda olan kişiler de kendi kararlarını grubun kararlarıymış gibi yansıtmaktadır. Güçlü olmanın kalıp yargılama eğilimini artırdığı sonucuna ulaşmak mümkün görülmektedir. Güç mesafesi, gücün dağılımının eşit olmamasını kabullenme, güçlü bireyler tarafından alınan kararların denetlenme ihtimalinin azlığı anlamını taşıyacağından, güç mesafesi yüksek toplumlarda güçlü olanların kalıp yargılama eğiliminin daha fazla olacağından söz edilebilir.

Diğer yandan, grupla birlikte sosyal kimlik edinen bireyler, grupları için biçimsel gördüklerine ve gruplarının kalıp yargılarına, grup önyargılarına uyum gösterme eğilimi içinde olmaktadır. Güç mesafesi yüksek olan toplumlarda, güce karşı boyun eğme, güce itaat etme eğilimi yüksek olduğundan, eşitsizliği kabullenmenin de etkisiyle hem grubun güçlü üyelerine itaat etme, hem de hiyerarşinin devam etme isteği dolayısıyla grup içi önyargıların ve grup dışına karşı önyargıların fazla olması beklenebilir. Dolayısıyla, güç mesafesi yüksek toplumlarda, grup kalıp yargılarının ve grup içi önyargıların daha fazla olması beklenebilir. Bu eğilim, güçlü gruplarda daha fazla görülebilir. Eğer bir toplumda güçlü olan bireyler kalıp yargılama eğiliminde ise, grupların, özellikle güçlü grupların kalıp yargılama eğiliminde olacakları, kalıp yargıların, grup içi önyargıları beraberinde getireceği değerlendirilebilir.

Öte yandan, ait olduğu gruba fayda sağlama, ödülleri kendi grubu içinde dağıtma olarak tarif edilebilecek olan iç grubu kayırma, eşitlik stratejisinden uzaklaşıldığında görülmekte ve grup içi, gruplar arası önyargılar, kalıp yargılar, grup içi kayırmacılığa neden olmaktadır. Dolayısıyla, güç mesafesi yüksek toplumlarda, grup kalıp yargılarının ve grup içi önyargıların da etkisiyle grup içi kayırmacılık eğiliminin artabileceği sonucuna varılabilir.

Güç konusuna statü açısından bakıldığında ise Sosyal Kimlik Kuramı, Sosyal Baskınlık Kuramı ve Sistemi Meşrulaştırma Kuramının öngörüleriyle, güç mesafesi yüksek toplumlarda, yüksek statülü gruplarda, grup içi kayırmacılığın yüksek olmasının beklenebileceği, grup içi kayırmacılığın, gruplar arası ayrımcıllğa neden olabileceği, düşük statülü gruplarda ise grup dışı kayırmacılığın yüksek olmasının beklenebileceği öngörülebilir. Güçlü gruplarda grup kalıp yargılarının ve grup içi önyargıların daha fazla olması beklendiğinden, grubun içinde bulunduğu ortam, çevresindeki diğer bireyler veya gruplar tarafından aktöre verilen statünün etkisiyle yüksek statülü 
gruplarda da kalıp yargıların ve grup içi önyargıların etkisiyle grup içi kayırmacılığın daha fazla olması beklenebilir.

Ayrıca, konuya statü açısından bakılmaya devam edildiğinde, eşitliğe karş1 olan tavırlar içinde GDB ve EM tavırlarına güç mesafesi yüksek olan toplumlar açısından bakıldığında, bu toplumlarda eşitsizliği kabullenme eğilimi ile birlikte yüksek statülü gruplarda EM eğilimi ve GDB eğiliminin, grup içi kayırmacılık ile gruplar arası ayrımcılığa neden olabileceği, düşük statülü gruplarda ise grup dışı kayırmacılığın görülebileceği değerlendirilebilir. Güç mesafesi yüksek toplumlarda eşitsizliğin kabullenilmesi, eşitsizliğin doğal yaşamın bir parçası olarak görülmesi, yüksek statülü grubun baskınlığına, ayrıcalıklarına devam etmek istemesi, eşit olmayı istememesi, kayırmacılık ve ayrımcıllı̆ 1 beraberinde getirecektir.

Güç mesafesi konusu, örgüt içindeki bireyler açısından ele alındığında ise güç mesafesi yüksek toplumlarda ve bu toplumların örgütlerinde, güç, hiyerarşiden ve pozisyondan dolayı elde edilmişse güç sahibi olanın sert etki taktikleri uygulaması, güç, teknik bilgi ve uzmanlıktan dolayı elde edilmişse de güç sahibi olanın yumuşak etki taktikleri uygulaması beklenebilir. Güç sahibi olan uzmanlıktan yoksunsa, astlarının kendisine itaat etmesini sağlamak ve karar verici olanın kendisi olduğunu vurgulamak üzere sert etki taktikleri uygulaması beklenebilir.

Sonuç olarak, güç mesafesi yüksek olduğunda, güçlü birey ve grupların, mevcut durumlarında ellerinde bulundurdukları avantajların devamlılığını sağlamak üzere eşitsizlik isteyecekleri, eşitliğe muhalefet edecekleri, eşitsizliğin devamını talep edecekleri öngörülebilir. Elbette ki bu duruma, güçsüz olanların eşitsizliği kabullenmelerinin olanak sağladığı, yol açtığı değerlendirilebilir. Bundan sonra yapılacak çalışmalarda, güç mesafesinin örgüt, birey ve grup bağlamında diğer olgulara yansıması ile örgütler aras1 ilişkiler üzerindeki etkileri araştırılabilir.

\section{Kaynakça}

Ayman, Roya, Martin M. Chemers ve Fred Fiedler (1995), "The Contingency Model of Leadership Effectiveness: its Level of Analysis", Leadership Quarterly, 6 (2): 147-167.

Balaban, Çiğdem D. (2013), "Türklerin Kürtlere Yönelik Önyargısını Yordamada Gruplar Arası Tehdidin, Sosyal Baskınlık Yöneliminin ve Sağ Kanat Yetkeciliğin Rolü ”, Yüksek Lisans Tezi, (Ankara: ODTÜ Sosyal Bilimler Enstitüsü).

Bayram, Fatma N. (2008), "Cinsiyet Rolleri, İlgi Etiği ve Sosyal Baskınlık Yönelimi: Hiyerarşiye Feminen Bir Bakış”, Yüksek Lisans Tezi (İstanbul: Boğaziçi Üniversitesi Sosyal Bilimler Enstitüsü). 
Dasgupta, Nilanjana (2004), "Implicit Intergroup Favoritism, Outgroup Favoritism and Their Behavioral Manifestations", Social Justice Research, 17 (2): 143-169.

De Dreu, Carsten K. W. ve Gerben A.Van Kleef (2004), "The Influence of Power on The Information Search, Impression Formation, and Demands in Negotiation", Journal of Experimental Social Psychology, 40: 303-319.

Ebenbach, David H. ve Dacher Keltner (1998), "Power, Emotion and Judgemental Accuracy in Social Conflict: Motivating the Cognitive Miser", Basic and Applied Social Psychology, 20 (1): 7-21.

Emerson, Richard M. (1962), "Power - Dependence Relations”, American Sociological Review, 27 (1): 31-41.

Ghosh, Apoorva (2011), "Power Distance in Organizational Contexts- A Review Of Collectivist Cultures", The Indian Journal of Industrial Relations, 47 (1): 89-101.

Goodwin, Stephanie A., Alexandra Gubin, Susan T. Fiske ve Vincent Y. Yzerbyt (2000), "Power can Bias Impression Processes: Stereotyping Subordinates by Default and by Design", Group Processes and Intergroup Relations, 3 (3): 227-256.

Haslam, S. Alexander, Stephen D. Reicher ve Katherine J. Reynolds (2012), "Identity, Influence and Change: Rediscovering John Turner's Vision For Social Psychology", British Journal of Social Psychology, 51 (2): 201-218.

Hewstone, Miles, Mark Rubin ve Hazel Willis (2002), "Intergroup Bias", Annual Review of Psychology, 53 (1): 575-604.

Hindriks, Paul, Maykel Verkuyten ve Marcel Coenders (2014), "Dimensions of Social Dominance Orientation: The Roles of Legitimizing Myths and National Identification", European Journal of Personality, 28 (6): 538-549.

Ho, Arnold K., Jim Sidanius, Felicia Pratto, Shana Levin, Lotte Thomsen, Nour Kteily ve Jennifer Sheehy-Skeffington (2012), "Social Dominance Orientation: Revisiting the Structure and Function of a Variable Predicting Social and Political Attitudes", Personality and Social Psychology Bulletin, 38 (5): 583-606.

Hofstede, Geert (1983a), "National Cultures in Four Dimensions", International Studies of Management and Organization, 13 (1-2): 46-74.

Hofstede, Geert (1983b), "The Cultural Relativity of Organizational Practices And Theories”, Journal of International Business Studies, 14 (2): 75-89.

Hofstede, Geert (1985), "The Interaction Between National and Organizational Value Systems", Journal of Management Studies, 22 (4): 347-357.

Hogg, Michael A., John C. Turner ve Barbara Davidson (1990), "Polarized Norms and Socia Frames of Reference: A Test of the Self-Categorization Theory of Group Polarization" Basic and Applied Social Psychology, 11 (1), 77-100.

Hogg, Michael A. ve Deborah J. Terry (2000), "Social Identity and Self-Categorization Processes in Organizational Contexts”, Academy of Management Review, 25 (1): 121-140.

Johnson, Camille S. ve Joris Lammers (2012), "The Powerful Disregard Social Comparison Information", Journal of Experimental Social Psychology, 48 (1): 329-334.

Jost, John T., Brett W. Pelham ve Mauricio R. Carvallo (2002), "Non-Conscious Forms of System Justification: Implicit and Behavioral Preferences for Higher Status Groups", Journal of Experimental Social Psychology, 38 (6): 586-602.

Jost, John T. ve Erik P. Thompson (2000), “Group-Based Dominance and Opposition to Equality as Independent Predictors of Self Esteem, Ethnocentrism and Social Policy Attitudes 
among African Americans and European Americans", Journal of Experimental Social Psychology, 36 (3): 209-232.

Karaçanta, Hatice (2002), "Üniversite Öğrencilerinin Sosyal Baskınlık Yönelimi ve Başka Bazı Değişkenler Açısından Karşılaştıııması”, Yayımlanmamış Doktora Tezi (Ankara: Ankara Üniversitesi Sosyal Bilimler Enstitüsü).

Khatri, Naresh (2009), "Consequences of Power Distance Orientation in Organizations", The Journal of Business Perspective, 13 (1): 1-9.

Klocke, Ulrich (2009), "I am the Best : Effects of Influence Tactics and Power Bases on Powerholders' Self Evaluation and Target Evaluation", Group Processes and Intergroup Relations, 12 (5): 619-637.

Koslowsky, Meni, Joseph Schwarzwald ve Sigal Ashuri (2001), "On the Relationship between Subordinates' Compliance to Power Sources and Organizational Attitudes", Applied Psychology:An International Review, 50 (3): 455-476.

Krackhardt, David (1990), "Assessing the Political Landscape: Structure, Cognition and Power in Organizations", Administrative Science Quarterly, 35 (2): 342-369.

Kugler, Matthew B., Joel Cooper ve Brian A. Nosek (2010), "Group-Based Dominance and Opposition to Equality Correspond to Different Psychological Motives", Social Justice Research, 23 (2): 117-155.

Leikas, Sointu, Jan - Eric Lönnqvist, Markku Verkasalo ve Vesa Nissinen (2013), "Power and Personality Perception in Real-Life Hierarchical Relationships", European Journal of Personality, 27 (2): 155-168.

Levin, Shana, Christopher M. Federico, Jim Sidanius ve Joshua L. Rabinowitz (2002), "Social Dominance Orientation and İntergroup Bias: The Legitimation of Favoritism for High Status Groups", Personality and Social Psychology Bulletin, 28 (2): 144-157.

Magee, Joe C (2009), "Seeing Power in Action: The Roles of Deliberation, Implementation and Action in Inferences of Power", The Journal of Experimental Social Psychology, 45 (1): 114

Magee, Joe C. ve Adam D. Galinsky (2008), "Social Hierarchy: The Self-Reinforcing Nature of Power and Status", Academy of Management Annals, 2 (1): 351-398.

Molm, Linda D. (1988), "The Structure and Use of Power: A Comparison of Reward and Punishment Power", Social Psychology Quarterly, 51 (2): 108-122.

Overbeck, Jennifer R. ve Vitaliya Droutman (2013), "One for All: Social Power Increases SelfAnchoring of Traits, Attitudes and Emotions", Psychological Science, 24 (8): 1466-1476.

Overbeck, Jennifer R. ve Bernadette Park (2006), "Powerful Perceivers, Powerless Objects: Flexibility of Power Holders' Social Attention", Organizational Behavior and Human Decision Processes, 99 (2): 227-243.

Overbeck, Jennifer R., John T. Jost, Cristina O. Mosso ve Agnieszka Flizik (2004), "Resistan Versus Acquiescent Responses to Ingroup Inferiority as a Function of Social Dominance Orientation in the USA and Italy", Group Processes and Intergroup Relations, 7 (1): 3554

Poppe, Edwin ve Hub Linssen (1999), "In-Group Favouritism and the Reflection of Realistic Dimensions of Difference Between National States in Central and Eastern Europe and Nationality Stereotypes", British Journal of Social Psychology, 38 (1): 85-102.

Robbins, Jordan M. ve Joachim I. Krueger (2005), "Social Projection to Ingroups and Outgroups: A Review and Meta-Analysis", Personality and Social Psychology Review, 9 (1): 32-47. 
Rodríguez-Bailón, Rosa, Miguel Moya ve Vincent Yzerbyt (2000), "Why do Superiors Attend to Negative Stereotypic Information About Their Subordinates? Effects of Power Legitimacy on Social Perception", European Journal of SocialPsychology, 30 (5): 651-671.

Rosenblatt, Valerie (2012), "Hierarchies, Power Inequalities and Organizational Corruption", Journal of Business Ethics, 111 (2): 237-251.

Rubin, Mark ve Miles Hewstone (2004), "Social Identity, System Justification and Social Dominance: Commentary on Reicher, Jost et al. and Sidanius et al.", Political Psychology, 25 (6): 823-844

Sachdev, Itesh ve Richard Y. Bourhis (1991), "Power and Status Differentials in Minority and Majority Group Relations", European Journal of Social Psychology, 21 (1): 1-24.

Salancik, Gerald R. ve Jeffrey Pfeffer (1977), "Who Gets Power - and How They Hold on to it: A Strategic-Contingency Model of Power", Organizational Dynamics, 5 (3): 3-21.

Sidanius, Jim ve Felicia Pratto (2004), "Social Dominance Theory: A New Synthesis", Jost, John T. ve Jim Sidanius (Der.), Political Psychology (New York: Psychology Press): 420-442

Smith, D. Randall, Nancy DiTomaso, George F. Farris ve Rene Cordero (2001), "Favoritism, Bias and Error in Performance Ratings of Scientists and Engineers: The Effect of Power, Status and Numbers", Sex Roles, 45 (5-6): 337-358.

Tajfel, Henri ve John C. Turner (1979), "The Social Psychology of Intergroup Relations", William G. Austin \& Stephen Worchel (Der.), An Integrative Theory of Intergroup Conflict, (Monterey,CA: Brooks-Cole): 33-47.

Turner, John C. (1975), "Social Comparison and Social İdentity: Some Prospects for İntergroup Behaviour", European Journal of Social Psychology, 5 (1): 5-34.

Turner, John C. (2005), "Explaining the Nature of Power: A Three-Process Theory", European Journal of Social Psychology, 35: 1-22.

Voci, Alberto (2006), "Relevance of Social Categories, Depersonalization and Group Processes: Two Field Tests of Self Categorization Theory", European Journal of Social Psychology, 36 (1): 73-90.

Votaw, Dow (1966), "What do We Believe About Power?", California Management Review, 8 (4) 71-88.

Whitson, Jennifer A., Katie A. Liljenquist, Adam D. Galinsky, Joe C. Magee, Deborah H. Gruenfeld ve Brian Cadena (2013), "The Blinding Leading: Power Reduces Awareness of Constraints", Journal of Experimental Social Psychology, 49: 579-582.

Wyer, Natalie A. (2010), "Selective Self-Categorization: Meaningful Categorization and the InGroup Persuasion Effect", The Journal of Social Psychology, 150 (5): 452-470.

Yıldırım, Necip ve Serap Akgün (2013), "Sivil Toplum Kuruluşu Gönüllülerinin Sosyal Sistemin Meşruiyetine İlişkin Algıları, Adil Dünya İnançları ve Sosyal Baskınlık Yönelimleri ", Toplum ve Sosyal Hizmet, 24 (1): 115-128.

Yılmaz, Muzaffer E. (2014), "Social Identity and Social Conflicts", Tesam Akademi Dergisi, 1 (2): 137-151.

Zhang, Yinlong, Karen Page Winterich ve Vikas Mittal (2010), "Power Distance Belief and Impulsive Buying", Journal of Marketing Research, 47 (5): 945-954. 